\title{
THE STRUCTURAL-GEOLOGICAL CONDITIONS OF FORMATIONS FOR DYKE BODIES WITHIN THE UKRAINIAN SHIELD
}

\author{
N.N. Shatalov \\ (Recommended by doctor of geological-mineralogical sciences L.S. Galetsky)
}

INSTITUTE of GEOLOGICAL SCIENCES of NAS UKRAINE, Kiev, Ukraine,

E-mail: geoi@bigmir.net

Doctor of geological sciences, senior scientific worker.

Structural geological, age and petrologic characteristics of dyke rocks of the Ukrainian Shield. Of dyke rocks of the swarms of geoblock the East-European platform.

Key words: dyke, dyke swarms, fault zones, Ukrainian shield.

\section{СТРУКТУРНО-ГЕОАОГІЧНІ УМОВИ ФОРМУВАННЯ ААЙКОВИХ УТВОРЕНЬ УКРАЇНСЬКОГО ЩИТА}

\author{
М.М. Шаталов
}

(Рекомендовано д-ром геол.-мінерал. наук Л.С. Галечьким)

Інститут геологічних наук НАН України, Київ, Україна,

E-mail: geoi@bigmir.net

Доктор геологічних наук, старший науковий співробітник.

Наведені структурно-геологічні, вікові і петрографічні особливості дайкових порід Українського щита. Розглядається зв'язок дайок і дайкових поясів з розломно-блоковими структурами кристалічного фундаменту регіону, який є частиною Східно-Європейської платформи. Ключові слова: дайки, дайкові пояси, розломи, Український щит.

\section{СТРУКТУРНО-ГЕОАОГИЧЕСКИЕ УСАОВИЯ ФОРМИРОВАНИЯ ААЙКОВЫХ ОБРАЗОВАНИЙ УКРАИНСКОГО ЩИТА}

\author{
Н.Н. Шаталов \\ (Рекомендовано д-ром геол.-минерал. наук Л.С. Галеиким)
}

Институт геологических наук НАН Украины, Киев, Украина,

E-mail: geoi@bigmir.net

Доктор геологических наук, старший научный сотрудник.

Приведены структурно-геологические, возрастные и петрографические особенности дайковых пород Украинского щита. Рассматривается связь даек и дайковых поясов с разломноблоковыми структурами кристаллического фундамента региона, являющегося частью Восточно-Европейской платформы.

Ключевые слова: дайки, дайковые пояса, разломы, Украинский щит.

(c) N.N. Shatalov, 2014 
The dyke bodies in the complicated heterogenic and multi-storeyed structure of the Ukrainian Shield (USh) crystalline basement are wide-spread occurred [Akhmetshina, 1975; Akhmetshina, 1980; Shatalov, 1986]. The dykes and dyke swarms with the different substance composition and age as the indicators of the deep fault zones and their junctions indicating certain stages of the Precambrian platform activation are the important tectonomagnetic structures. The analysis of geoblock tectonic activation, fault zones, and geological structural dyke positions in their boundaries is crucial in the retrospective assessment for magmatism, evolution, and ore occurrence in the regional crust. As the various mineral deposits coincide with the faults and their junctions within the USh and the structures surrounding it, the identification of structural position, spatial locality patterns, substance composition, age, and metallogenic specificity of each dyke and the dyke swarms represent both the scientific and commercial interest.

The dykes and dyke swarms on the raised area of the Pre-Riphean USh crystalline basement have received the most study, where the sedimentary mantle is low thick or absent at all. The USh megablocks (such as Volynsky, Kirovogradsky, Near-Dnieperian, Near-Azovian ones, etc.) at the different sizes and substance compositions are fragmented here by the system of the ravines, large rivers and their tributaries. A lot of particular dykes and dyke swarms are exposed by the quarries and mapped by the numerous exploration holes. In the structures framed the USh, where the Precambrian basement is underwent the considerable subsidence, the dyke bodies are overlapped by the thick sedimentary mantle (from tens of meters to some kilometers) of the different composition and age, for the some areas the dykes are indicated therein by the geophysical methods and pervaded by drilling holes.

The specific characteristics of the tectonics for the USh crystalline basement is the zones with the high fissuring and the large faults healing with dyke series at the different compositions, age and dimensional orientation. Dyke concentration within dyke swarms (belts, zones) manifested rather explicitly is the general geological and structural features of dyke occurrence of the USh (Fig. 1). The tectonic processes induced the occurrence of dyke swarms were crucial in the forming fault-block structures (blocky ones) of the USh and its margins. The dyke swarms confirmed with the regional fault -block zones, the fragments of global fault systems and the nodes of intersection among themselves are tracked with the field geological and structural, geophysical as well as aerospace methods.

In most cases the dyke swarms are coincided spatially and structurally with the distinguished USh's fault zones such as the Central, Devladovsky, Dnieper-Dzerzhynsky, Subbotsko-Moshorynsky, Kamennomohylsky, Maloyanisopolsky, Octiabrsky, and others. Thus the structure control of dyke and dyke swarms location on the USh is realized by the different oriented deep fault zones and their fragments. Some dyke swarms of the USh and the structural nodes of intersection among themselves as well as intersection of the dykes with the fault zones of the different spreading may be connected with the positive regional magnetic anomaly [Krutikhovskaia et al., 1976]. However the nature of this connection isn't still elucidated to a full degree, while the close structural and positional relations between the dyke intersection nodes and the Novograd-Volynsky, West Ingulets, Sinelnikovien, West Near-Azovian and other regional magnetic anomalies for the USh may be of scientific and commercial interest when studying the ore occurrences and interaction between the subsurface Precambrian structures and substance composition of the lithosphere's lower layers.

The formation of dyke series and dyke swarms for the USh is associated with the relative vertical displacements (with some shear component) for the consolidated geoblocks of the crystalline basement along the faults parting them in mode of dominant expansion. In this case the displacements of the rigid Precambrian geoblocks along the fault zones should be carried out by differentiate shifts of the rather thin "plates" composed of fault structures as well as have induced a lot of subparallel ruptures, which were filled in magma immediately (in the geological chronology) creating the cognate dyke series.

When the summarized horizontal shear component of the geoblock displacement of the basement were considerable (hundreds of meters and more), the penetration of magmatic melts and formation of dykes have been also proceeded through the shear feathering fis- 
sures, i.e. at the acute angle $\left(10^{\circ}-30^{\circ}\right)$ to the principle direction of the fault zone enclosed the series of subparallel dyke bodies. As an illustration of similar dyke formation, when the dyke penetration is caused by the relative geoblock shifts in the vertical and horizontal directions it may be mentioned the Kuznetsovo-Mikhailovsky, Anton-Taramsky, Pavlopol-Oktiabrsky, Maloyanisopolsky, Kamennomohylsky dyke swarms from the Near-Azovian region. Here the series of separate thin dykes (apophysis from the large dyke bodies) spreading at the acute angle to the series of relative thick subparallel ones are developed. In the mentioned belts the shifts of the aplitic, quartz, and pegmatite veins are seen, and the dykes of diabases, lamprophyres and different rocks cut off them giving evidence the shear displacements in the process of dyke formation. The recent erosion truncation features as well as the complex of aerospace, geological, and geophysical data for the mentioned above Near-Azo-vian dyke swarms enable to classify them as the left-lateral strike-slips [Bystrevskaia \& Shatalov, 1980; Shatalov, 1986].

The dykes and dyke swarms striking within the USh are earlier studied statistically [Akhmetshina, 1975; Krutikhovskaia et al., 1976; Shatalov, 1986] by the measurements of dyke orien- tation in the outcrops in the field structural and geological investigations as well as in the process of the drilling and geophysical operations (Fig. 2). In the last case the dyke strike data are obtained in the linear magnetic anomaly validation with the drilling or according to orientation of the anomalies alone. The analysis of rose diagrams for the dyke strike shows that the dykes within the USh are spreading non-randomly and form the mutually perpendicular orthogonal and diagonal systems coinciding in the whole with the strikes of the known deep fault systems, which are considered within the USh by V. H. Bondarchuk, I. I. Chebanenko, A.V. Chekunov, V.B. Sollohub, O.B. Hintov, K. F. Tiapkin, A.A. Hontarenko, V.A. Riabenko, H.I. Kaliaev, L.S. Galetsky, H.T. Sobakar, A.A. Hoizhevsky, I.S. Potapchuk, V.I. Aliekhin, A.T. Azimov, etc.

The coincidence between dyke orientations and the deep faults proves their genetic affinity and shows that the dyke formations have selectively used the global and regional fissuring systems, which were actively occurred at the certain stages of tectonic - magmatic activation and evolution of the Ukrainian Shield.

The USh dykes of the north-west strike $\left(\mathrm{E}-\mathrm{W} 300^{\circ}-310^{\circ}\right.$ and $320^{\circ}-330^{\circ}$ ) are the most abundant, while the dykes of sub-latitudinal

Fig. 1. Scheme of the locations for mafic dyke swarms within the Ukrainian Shield

I - dyke swarms (the figures in circles): 1 - Kuznetsovo-Mikhailovsky, 2 - Anton-Taramsky, 3 - Pavlopol-Oktiabrsky, 4 Maloyanisolsky, 5 - Kamennomohilsky, 6 - Yeliseevsky, 7 - Bazavluksky, 8 - Devladovsky, 9 - Piatikhatsky, 10 - Chertom-

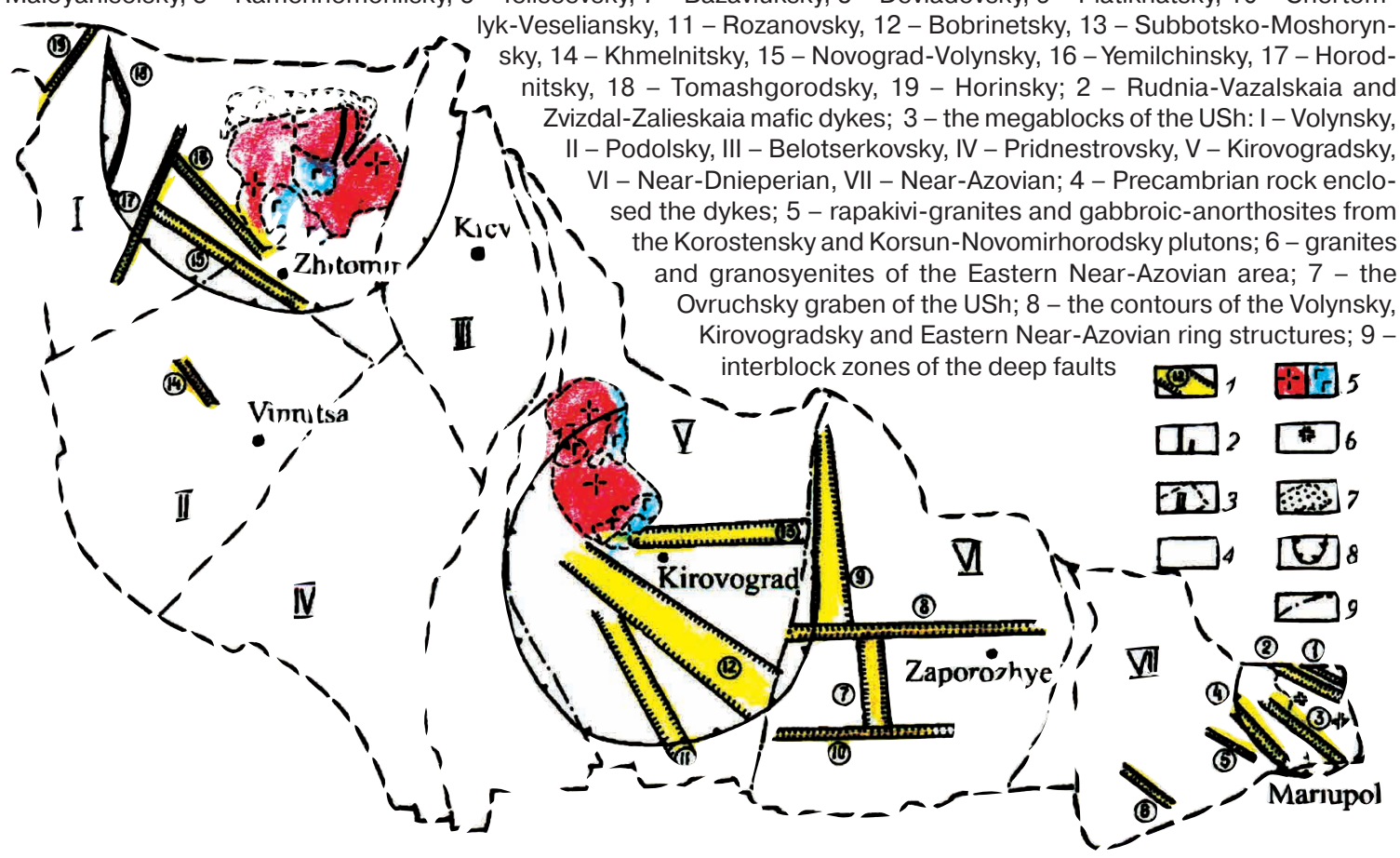


and sub- longitudinal strikes are less and the dykes of north-east strike are least spreading. The system of dykes at the azimuth of $320^{\circ}$ may be considered as the global one, and the dykes of $300^{\circ}$ strike are connected with the regional system of fissuring for the shield's rocks induced by the shield forming as the large positive structure of the basement of East-European platform [Galetsky, 1993].

Reflecting the specific particularities of geological and structural evolution and tectonicmagmatic activation, the megablocks of the USh are differed among those through the predominant directions of dyke strikes, which are located into their borders. In the Easter NearAzovian geoblock, the Kirovogradsky and Volynsky megablocks the dykes of N-E strike are prevalent and the dykes of the sub- Iongitudinal and sub-latitudinal are wider spreading in the Western Near-Azovian geoblock and essentially the Near-Dnieperian megablock.

There is the certain relationship among the strike, petrographic composition, and age of dykes. The ultrabasic dykes are characterized by the latitudinal directions, the basic dykes is N-W and sub-longitudinal spreading, and the acidic dykes are occurred in all directions. On the whole the dykes of sub-latitudinal and sub-longitudinal strikes are the Archean-Paleoproterozoic age and N-W dykes are Neoproterozoic one.

Observing the interrelations between the dykes and host rocks within the different geoblocks under the field conditions it is easy to ascertain that the special orientation and localization of the dykes and dyke swarms as a rule don't depend on the structure of USh Precambrian basement controlled by fault-block tectonics, which is reflected the regional anisotropy of heterogeni, slaty-block rocks, and the most eroded crystalline ones of the Archean and Proterozoic ages [Akhmetshina, 1980; Gintov, 1983; Glevassky, 2000].

The single dykes and dyke swarms of the different compositions and ages usually cut the all host rocks of Precambrian age. This kind of "dyke - host rock framework" interrelation is proved by the structural-geological, geophysical, and aerospace data. It is important to emphasize that despite such relations with the host rock of the Precambrian age the dykes occurring here are the different ages, having been formed for the Neo-Archean to the Mesozoic period [Bernadskaia et al., 1985;
Bukharev \& Poliansky, 1986; Grechishnikov et al., 1980; Shatalov, 2002; Shatalov, 2007].

The structural-geological, geophysical, and aerospace studies within the Volynsky megablock and Volyno-Polessky plutonogenic belt have shown that the dykes and dyke swarms cut the gneiss - magmatic complexes of Precambrian age consisting of the fine folded synclinal and anticlinal structures of $\mathrm{N}$ W strike in the various directions and at the different angles. Moreover they cut also the granitoid massifs associated with the last and lie into the cores of dome and brachy-anticline structures of the higher ranks.

In the Central Volynsky geoblock the dykes of ultrabasites, lamprophyres, andesite porphyrites, diabases, gabbro-diabases, and diabasic porphyrites, cut off at the acute and right angles, for instance, the Novgorod-Volynsky and Krasnohorsko- Zhytomirsky arches, which are the narrow elongate regional folded structures of anticlinal character. Besides they assemble a number of the domes and brachyanticlines, which are hosted mainly the porphyraceous massifs (Serbovsky, Chyzhovsky, Aleksandrovsky, Novgorod - Volynsky, Bronikovsky, Yavorsky, Tartaksky, Kamennobrodsky, Luhovskoy, Cherniavsky, etc.) of the granitoids from the Kirovogradsko-Zhytomirsky complex [Shcherbak et al., 2008]. As for the dykes of lamprophyres, gabbro-diabases, diabases and other rocks they are "cutting off" by the Belokorovichsky graben-syncline and the complicated Korostensky subsequent folded pluton [Bukharev \& Poliansky, 1986; Shcherbak et al., 2008]. The younger dyke group of diabases, gabbro-diabases, granite-porphyries, quartz porphyries, and orthophyres cross the massifs of anorthosites and rapakivi-granites from the Korostensky pluton and is "cutting off" by the Ovruchsky sublatitudinal graben-shaped structure.

The mafic dykes of the protoplate evolution stage within the Kirovohradsky megablock forming the thick Rozanovsky, Bobrinetsky, Novoukrainsky, and Subbotsko-Mashorinsky dyke swarms of N-W and sublatitudinal strike cut the folded structures distinguishing in this region such as the Inhuletsky and Bratsky synclinoria, the Novoukrainsky anticlinorium, the Shpoliansky syncline, as well as the Western Inhuletsky arch consisted of the series of small granitic domes and brachy-anticlines [Grechishnikov et al., 1980; Glevassky, 2000; Kali- 

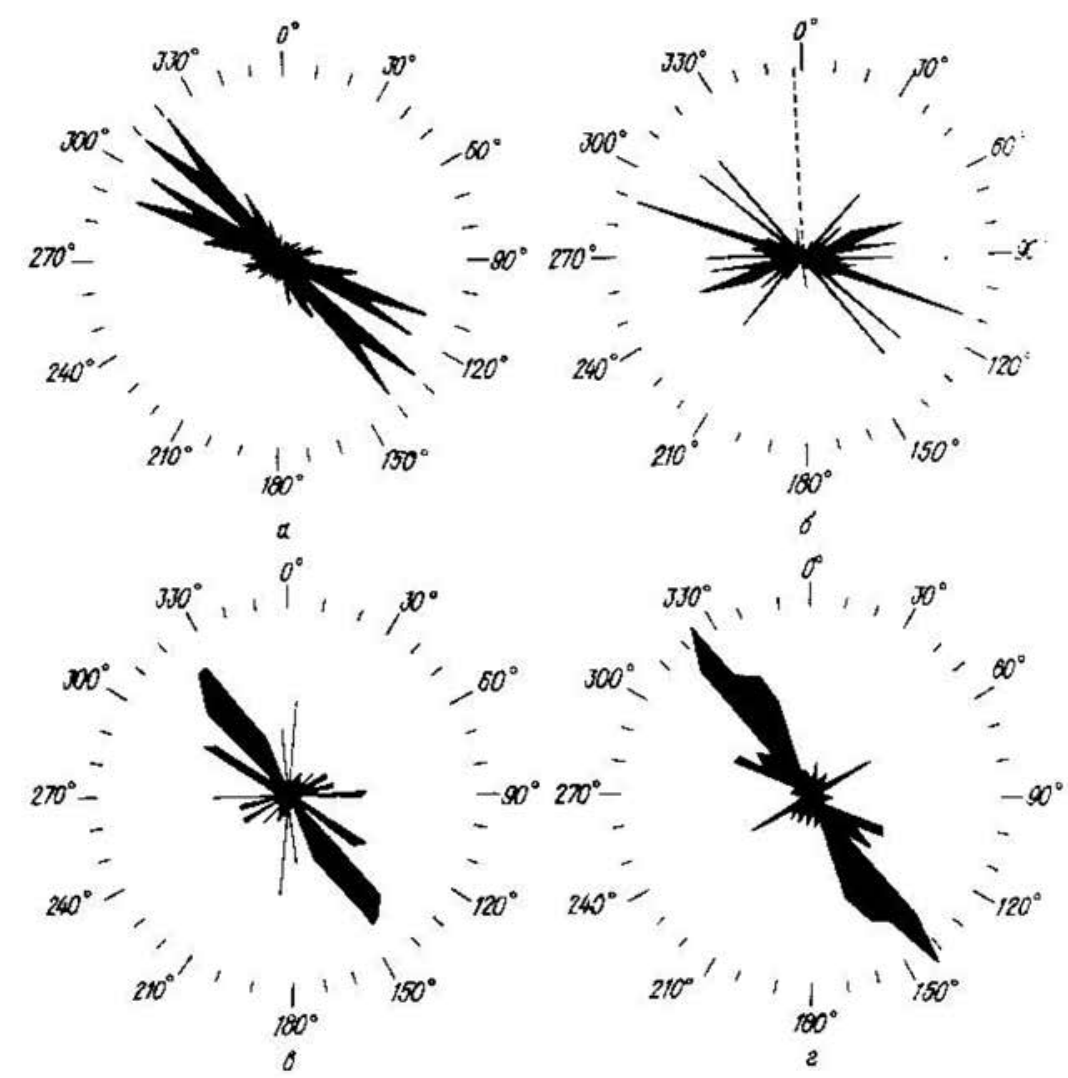

Fig. 2. Diagram of dyke strikes over the Near-Azovian massif (a, b), the Ukrainian (c) and Canadian (d) Shields [Shatalov, 1986]

aiev et al.,1980; Kiriliuk, 2010; Kiriliuk \& Smogaliuk, 1993].

As far as the Near-Dnieperian megablock the dyke swarms with the relatively large sizes, sub-latitudinal and sub-longitudinal strike (Piatikhatsky, Dneprodzerzhynsky, Bazavluksky, Chertomlyksko-Veseliansky, Konksky, Devladovsky) cut the wide spreading here plagiogranite-gneiss domes and arches (Piatikhatsky, Demurinsky, Saksahansky, Krynychansky, Novoaleksandrovsky, Kamyshevakhsky, etc.) at the different angles. They cut also the structures of syncline or monocline constructions described by many scientists [Glevassky, 2000; Kaliaiev et al., 1980] as "the greenstone troughs" (Kobeliaksky, Verkhovtsevsky, Chertomlyksky, Shyrokovsky, Sursky, Konksky, Derezovatsky, Beloziorsky, etc.).

The field structural-geological, geophysical, and aerospace studies of the Near-Azovian megablock of the USh show that the dyke bodies of N-W and sub-latitudinal strike constituted the thick dyke swarms in the crystalline basement, i.e. the Kuznetsovo-Mikhailovsky, Anton-
Taramsky, Pavlopol-Oktiabrsky, Maloyanisopolsky, Kamennomogilsky, Eliseevsky, and other ones, cut the largest plicative structures of this region in the different directions. These include the Telmanosky, Kamyshevakhsky, Saltychansky and Andreievsky domical structures, Removsky anticline, Central Near-Azovian and Korsaksky synklinoria.

Analyzing the patterns in the dyke body occurrences one can see that the large USh's megablocks vary in the dyke abundance, substance composition, and age, as well as in the prevalent directions of their strike. The dykes and dyke swarms spreading are generally associated with the features of deep construction and the inner structure of megablocks, as well as Archean and Proterozoic and latter archblocky and blocky movements of the megablocks and their some parts.

In order to elucidate the level of dyke saturation in the megablocks it is important to analyze also the dyke disposal patterns among the geoblocks, characterizing by the femic and sialic types of the crust. This analysis comes 
from the determination (using aerospace and geological-geophysical data) of the lateral and vertical heterogeneities in the structure and substance composition for the megablocks and geoblocks, which are formed as a result of the long evolution of the Precambrian paleo-lithosphere of the Ukrainian Shield. The analysis of hetero-geneities in the paleo-lithosphere may explains both the dyke saturation for the various megablocks and gains a better understanding of the peculiarities of dimen-sional orientations, substance composition, and the age, as well as the petroche-mical, geochemical, and metallogenic specialization of the dyke rocks, localized in the USh's megablocks differed in the substance composition and the age.

At the present time it is possible to distinguish three large megablocks from the multidimensional Precambrian USh structure such as the Volyno-Podolsky, Central-Ukrainian, and Near-Azovian ones. They are detached from each other by the Holovanovsky and OrekhovoPavlohradsky suture zones. The mentioned megablocks are divided into some first rank megablocks by the fault system and inter-block zones, i. e. the Volyno-Podolsky megablock into the Podolsky, the Belotserkovsky, and the Pridnestrovsky first rank megabloks; the Central-Ukrainian one - into Kirovohradsky and Near-Dnieperian first rank ones.

Moreover, a number of geoblocks of the first ranks are in turn distinguished within the megablocks of the first rank, for instance the Volynsky megablock is separated into the Horynsky, Osnitsky, Novohrad-Volynsky, and Korostensky geoblocks by the systems of first rank faults (like the Brusilovsky, Teterevsky, Sarnensko-Varvarovsky, Horynsky, Perzhansky, Yemilchansky ones, etc.). In the borders of the Kirovogradsky megablock there are the Novoukrainian and Inhuletsky geoblocks, as well as the the Verkhovetsky, Zaporozhsky, and Levoberezhny geoblocks in the Near-Dnieperian megablock, the West Near-Azovian and East Near-Azovian geoblocks in the Near-Azovian megablock, respectively. As for the West Near-Azovian geoblock the relative smaller geoblocks of the second rank, i.e. the Volchansky, Huliaipolsky, and Andrieevsky ones are distinguished.

The majority of dykes and dyke swarms in the tectonic sense are localized within the Volynsky, Kirovogradsky, Near-Dnieperian, and Near-Azovian megablocks of the USh. As far as the other megablocks there the dykes are rarely occurred or extended in general sporadically. As an instance the dyke swarms are absent in the Belotserkovsky and Pridnestrovsky megablocks, the dykes are sporadically developed in the Podolsky megablock of the USh. As far as the dyke abundance level, the substance composition, the age, and the dimensional orientation, the above mentioned more sialic megablocks of the USh are quite differed from each other also. In the whole the NearDnieperian and Near-Azovian megablocks are high saturated by the dykes, the Kirovogradsky and Volynsky are lower saturated. However, the latter megablock has the Rudnia-Bazarskaya and Zvizdal-Zalesskaya mafic dykes unusual for the Ukrainian Shield at the width to $2 \mathrm{~km}$ and the length more $50 \mathrm{~km}$. In addition to the many extensional mafic dyke bodies at the length to $25 \mathrm{~km}$ and the width to $200 \mathrm{~m}$ are found out in the north-western Volynsky megablock.

The concentration of dykes within the Volynsky, Kirovogradsky, Near-Dnieperian, and Near-Azovian megablocks is some differed also. For instance, the Easter Near-Azovian geoblock belonging to the Near-Azovian megablock is the most abundant and the western Near-Azovian one is less abundant by dykes. It is observed the younger rocks and rather patchy by composition (ultrabasic, basic, intermediate, acidic, alkali) localized into more sialic and "regenerated" Eastern NearAzovian geoblock, while the more ancient dykes of ultrabasic and basic compositions are predominantly developed in more femic Western Near-Azovian geoblock.

The more sialic Volynsky, Kirovogradsky, and Near-Azovian megablocksof the USh are characterized by the forming of the dykes connected structurally, dimensionally, and often genetically with the occurrence of basic rocks and rapakivi-granites from the Korostensky and Korsun-Novomyrgorodsky plutons, as well as granite massifs from the east Near-Azovian granosyenite complex. Within the Korostensky and Korsun-Novomyrgorodsky magmatic plutons and their surroundings the dykes of ultrabasite, diabase, gabbrodiabase, diabasic porphyrite, picrite, kimberlite, lamprophyre, granite-porphyre, qurtz porphyre, orthophyre, and other rocks are mapped. The dykes with more diverse substance compositions are localized in the Eastern Near-Azovian geoblock, 
in the evolution limits and the surroundings of the granite massifs of the Anadolsky type and granosyenite from the eastern Near-Azovian complex. Apart from the above petrographic types of dyke rocks, here the dykes of kimberlite, intermediate and alkali rocks (andesite, orthophyre, grorudite, etc.) are widespread.

Certain pattern of the dyke abundance for various USh's megablocks depends on the development of dyke bodies among the host rock areas undergone the different facies of metamorphism as the followings: granulitic, amphibolitic, epidote - amphibolitic, and greenschist ones. The data collected at present show the high dyke concentration in the Near-Dnieperian megablock, where the host rock is undergone the metamorphism of the epidote - amphibolitic, and greenschist facies. The Volynsky, Kirovogradsky, and Eastern Near-Azovian geoblocks of the USh are rather enriched by the dyke bodies, where the relative large areas of rock are metamorphosed under the conditions of the different stages of amphibolitic facies.

The dykes are sporadically developed (often absent at all) among the granulite-facies metamorphic rock. As is known [Grechishnikov et al., 1980; Glevassky, 2000; Kaliaiev et al., 1980; Kiriliuk \& Smogaliuk, 1993], granulite-facies rock is the most developed in the Podolsky and Pridnestrovian megablocks of the USh, where the dykes are practically absent. The diabase dykes from the Khmelnitsky dyke swarms of a N-W trending located in the Podolsky megablock are an illustrative example for this case (Fig. 1). Here the dykes are well traced among the host rock metamorphosed under the amphibolite facies conditions of metamorphism and they are absent in the granulite facies rock extended well to the S-E Khmelniksky belt.

he analysis of dykes and dyke swarms spreading patterns relative to the deep structure and crust thickness in the region shows their spatial and structural tendency to the areas with the thinning crust $(35-45 \mathrm{~km})$ and they are localized preferentially within the Volynsky, Kirovogradsky, Near-Dnieperian megablocks and the Eastern Near-Azovian geoblock of the USh. In the blocks with the thic-kening and more femic crust (Podolsky, Pridnestrovian,Western Pridnestrovian and others), where the highest metamorphic facies rocks are emerged at the Pre-Riphean surface and Moho discontinuity is detected at the depth of $50-55 \mathrm{~km}$ by DSS data the dykes and dyke swarms are enough restrictive developed or absent at all.

Thus the abundance of dykes and dyke swarms for the megablocks at the various substance compositions and the age in the whole are defined by the deep structure and the difference into endogenic forming conditions and evolution of paleo - lithosphere of the USh. Moreover the dykes and dyke swarms prove the lateral and vertical discontinuities for the regional crust, the grade of its destruction and maturity. Therefore, the dykes are the sensitive indicators both the metamorphism conditions and substance compositions as well as the age of the various parts of megablocks defined above, the changes of geodynamic state within their boundaries. The dykes and dyke swarms of the Archean - Paleo-Proterozoic age, for example, are characterized by the mafic composition and confined to more ancient geoblocks of the crystalline basement. They don't generally leave their geoblocks.

The dykes at the age of less $1.8 \mathrm{Ga}$ ago occurred due to the laying and evolution of graben-shaping troughs in surrounding of the USh (the Dono-Dnieperian, Ovruchsky ones and so on) have the more patchy composition and prefer the younger, regenerated and mature crust geoblocks of the USh, where they often cross over more and more minor multiage blocks and their borders. This tectonic and spatial distribution of the dykes and dyke swarms in the mega- and geoblock structure of the USh gives evidence of the regular and successive alteration of basite crust into granitoid consolidated one.

The above given data indicate that the manifestation of dyke magmatism for the USh are connected with the periodical disturbance of cratonal regime of the Eastern European platform and are confined to certain stages of its tectonic and magmatic activation. Among the dyke forms of the USh there are some aged groups of dykes clearly marked as the follows: $3000-2800 ; 2500-2300 ; 2200-2000 ; 1800$ - 1500; 1400 - 1100; 1000 - 900; 650 - 550; 400 - 330; 320 - 260; 220 - $200 \mathrm{Ma}$. The structural - chronological and petrologic characteristics for the number of dykes are earlier presented in the following publications [Akhmetshina, 1975; Shatalov, 1986; Shcherbak et al., 2005]. 


\section{References}

1. Ахметшина А.К. Анализ закономерностей пространственной ориентировки даек на Украинском и Канадском щитах. Докл. АН УССР. Сер. Б. 1975. № 1. С. 3-5.

Akhmetshina A.K., 1975. Dyke spatial orientation analysis for the Ukrainian and Canadian Shields. Dokl. AN USSR. Ser. B, № 1, P. 3-5 (in Russian).

2. Ахметшина А.К. Взаимосвязь дайковых образований с тектоническими этапами развития Украинского щита. Докл. АН СССР. 1980. Т. 22, № 5. С. 1201-1204.

Akhmetshina A.K., 1980. Relationship between dyke formations and tectonic stages of the Ukrainian Shield evolution. Dokl. AN SSSR, Vol. 22, № 5, P. 1201-1204 (in Russian).

3. Бернадская Л.Г., Котловская Ф.И., Шаталов Н.Н. Изотопный возраст дайковых формаций Украинского щита. Геохимия и рудообразование. 1985. № 13. С. 54-63.

Bernadskaia L.H., Kotlovskaia F.I., Shatalov N.N., 1985. Isotopic age of the dyke formations of the Ukrainian Shield. Geokhimiya i rudoobrazovanie, № 13, P. 54-63 (in Russian).

4. Бухарев В.П., Полянский В.Д. Позднепротерозойская толеит-базальтовая протрапповая формация северо-западной части Украинского щита. Геол. журн. 1986. Т. 46, № 3 (229). С. 65-73.

Bukharev V.P., Poliansky V.D., 1986. The Late Proterozoic tholeleiite-basalt pro-trappean formation for the east-western Ukrainian Shield. Geol. zhurnal, Vol. 46, № 3 (229), P. 65-73 (in Russian).

5. Быстревская С.С., Шаталов Н.Н. Глубинная структура земной коры по космическим изображениям (на примере Восточного Приазовья). Исслед. Земли из Космоса. 1980. № 5. С. 10-16.

Bystrevskaia S.S., Shatalov N.N., 1980. Abyssal earth crust structure from space images: Case of the eastern Near-Azovian area. Issledovanie Zemli iz Kosmosa, № 5, P. 10-16 (in Russian).

6. Галецкий Л.С. Основные этапы развития, геоблоковая делимость и минералогения Восточно-Европейской платформы. Геол. журн. 1993. № 4 (271). С. 3-9.

Galetsky L.S., 1993. The principle stages of evolution, geoblocky separability and minerogenesis for the East-European Shield. Geol. zhurnal, № 4 (271), P. 3-9 (in Russian).

7. Галецкий Л.С., Шаталов Н.Н., Потапчук И.С., Шаталов А.Н. Дайки и зоны метасоматитов Украинского щита: Тез. доп. наук. конф. «Теоретичні питання і практика дослідження метасоматичних порід і руд», 14-16 берез. 2012 р., м. Київ. Київ, 2012. С. 23-24.

Galetsky L.S., Shatalov N.N., Potapchuk I.S., Shatalov A.N. Dykes and Ukrainian Shield's metaso- matites: Proceedings of Sci. Conf. "Theoretical issues and practices for metasomatic rocks and ores exploration", March 14-16, 2012, Kiev, 2012, P. 2324 (in Russian).

8. Гинтов О.Б. Структуры континентальной земной коры на ранних этапах ее развития. Киев: Наук. думка, 1978. 164 с.

Gintov O.B. The continental earth crust structure at the early stages of its evolution. Kiev: Naukova Dumka, 1978. 164 p. (in Russian).

9. Гинтов О.Б., Исай В.М., Трипольский А.А. О характере блоковых движений в процессе формирования земной коры Украинского щита. Геол. журн. 1983. Т. 43, № 1 (208). С. 38-45.

Gintov O.B., Isay V.M., Tripolsky A.A., 1983. On a character of block movements in process of earth crust forming of the Ukrainian Shield. Geol. zhournal, Vol. 43, № 1 (208), P. 38-45 (in Russian).

10. Гречишников Н.П., Коржнева Е.П., Крамар O.A. и др. О возрасте дайковых пород Субботско-Мошоринской зоны разломов. Там же. 1980. T. 40, № 5 (194). C. 139-143.

Grechishnikov N.P., Korzhneva E.P., Kramar O.A. et al., 1980. On an age of dyke ores from the Subbotsko-Moshorynsky fault zone. Ibid., Vol. 40, № 5 (194), P. 139-143 (in Russian).

11. Глевасский Е.Б., Каляев Г.И. Тектоника докембрия Украинского щита. Минерал. журн. 2000. № 2-3. С. 77-91.

Glevassky E.B., Kaliaev H.I., 2000. Pre-Cambrian tectonics of the Ukrainian Shield. Mineral. zhurnal, № 2-3, P. 77-91 (in Russian).

12. Каляев Г.И., Крутиховская З. А., Рябенко B.A. и др. Тектоника раннего докембрия Украинского щита. Региональная тектоника раннего докембрия СССР. Ленинград: Наука, 1980. C. 18-32.

Kaliaev H.I., Krutikhovskaia Z.A., Riabenko V.A. et al. The Early Pre-Cambrian tectonics of the Ukrainian Shield. Regional tectonics of Early PreCambrian of USSR. Leningrad: Nauka, 1980. P. 1832 (in Russian).

13. Кирилюк В.П. Геотектонічна періодизація раннього докембрію. Геол. журн. 2010. № 3 (332). C. 111-119.

Kiriliuk V.P., 2010. Geotectonic periodization for the Early Pre-Cambrian. Geol. Journal, № 3 (332), P. 111-119 (in Ukrainian).

14. Кирилюк В.П., Смоголюк А.Г. Об основных структурных элементах этажно-блоковой стуктуры Украинского щита. Там же. 1993. № 3 (270). C. 54-69.

Kiriliuk V.P., Smoholiuk A.H., 1993. On basic elements of the stage-block structure of the Ukrainian Shield. Ibid., № 3 (270), P. 54-69 (in Russian). 
15. Крутиховская З.А., Пашкевич И.К., Подолянко С.М. и др. Закономерности распространения дайковых комплексов Украинского щита. Геофиз. журн. 1976. Вып. 74. С. 61-74.

Krutikhovskaia Z.A., Pashkevich I.K., Podolianko S.M. et al., 1976. The distribution laws of dyke complexes of the Ukrainian Shield. Geofiz. zhurnal, Issue 74, P. 61-74 (in Russian).

16. Салоп Л.И. Геологическое развитие Земли в докембрии. Ленинград: Недра, 1982. 343 с.

Salop L.I. Geological evolution of the Earth in the Pre-Cambrian. Leningrad: Nedra, 982. 343 p. (in Russian).

17. Соллогуб В.Б. Литосфера Украины. Киев: Наук. думка, 1986. 183 с.

Sollohub V.B. Lithosphere of Ukraine. Kiev: Naukova Dumka, 1986. 183 p. (in Russian).

18. Тяпкин К.Ф., Довбнич Н.Н. Новая ротационная гипотеза структурообразования и ее геолого-математическое обоснование. Донецк: Ноулидж, 2009. 219 с.

Tiapkin K.F., Dovbnych N.N. New rotation hypothesis of structure formation and its geologicalmathematical justification. Donetsk: Nowleadge, 2009. 219 p. (in Russian).

19. Чебаненко И.И. Теоретические аспекты тектонической делимости земной коры. Киев: Наук. думка, 1977. 82 с.

Chebanenko I.I. The theoretical aspects of tectonic separability of the Earth crust. Kiev: Naukova Dumka, 1977. 82 p. (in Russian).

20. Чекунов А.В. Структура земной коры и тектоника юга европейской части СССР. Киев: Наук. думка, 1972. 176 с.

Chekunov A.V. The earth crust structure and tectonics of the south European part of USSR. Kiev: Naukova Dumka, 1972. 176 p. (in Russian).

21.Шаталов Н.Н. Дайки Приазовья. Киев: Наук. думка, 1986. 192 с.

Shatalov N.N. The Near-Azovian dykes. Kiev: Naukova Dumka, 1986. 192 p. (in Russian).

22. Щербаков И.Б. Петрология Украинского щита. Львов: ЗУКП, 2005. 364 с.

Shcherbakov I.B. Petrology of the Ukrainian Shield. Lvov: ZUKP, 2005. 364 p. (in Russian).

23. Щербак Н.П., Артеменко Г.В., Лесная И.М., Пономаренко А.Н. Геохронология раннего докембрия Украинского щита. Архей. Киев: Наук. думка, 2005. 242 с.

Shcherbak N.P., Artemenko H.V., Lesnaia I. M., Ponomarenko A.N. The Early Pre-Cambrian geochronology of the Ukrainian Shield. The Archean. Kiev: Naukova Dumka, 2005. 242 p. (in Russian).

24. Щербак Н.П., Артеменко Г.В., Лесная И.М. и др. Геохронология раннего докембрия
Украинского щита. Протерозой. Киев: Наук. думка, 2008. 240 с.

Shcherbak N.P., Artemenko H.V., Lesnaia I.M. et al. The Early Pre-Cambrian geochronology of the Ukrainian Shield. The Proterozoic. Kiev: Naukova Dumka, 2008. 240 p. (in Russian).

25. Shatalov N.N., Shatalov A.N. On recent neotectonic processes within the proterozoic granitic massif "Kamennye mogily" (Near-Azov block of the Ukrainian Shield). Геол. журн. 1998. № 3-4 (286). C. 128-131.

Shatalov N.N., Shatalov A.N., 1998. On recent neotectonic processes within the proterozoic granitic massif "Kamennye mogily" (Near-Azov block of the Ukrainian Shield). Geol. zhurnal, № 34 (286), P. 128-131 (in English).

26. Shatalov N.N., Shatalov A.N. Mafic dyke swarms of the East-European platform. Там же. 2001. № 3 (207). C. 41-45.

Shatalov N.N., Shatalov A.N., 2001. Mafic dyke swarms of the East-European platform. Ibid., № 3 (207), P. 41-45 (in English).

27. Shatalov N.N., Shatalov A.N. Dykes rocks of Near-Azovian geoblock of the Ukrainian Shield. TaM же. 2002. № 2 (300). C. 49-54.

Shatalov N.N., Shatalov A.N., 2002a. Dykes rocks of Near-Azovian geoblock of the Ukrainian Shield. Ibid., № 2 (300). P. 49-54 (in English).

28. Shatalov N.N., Shatalov A.N. Dykes of the Ukrainian Shield. Part 1. Mafic dykes swarms. TaM же. 2002b. № 3 (301). C. 56-61.

Shatalov N.N., Shatalov A.N., 2002b. Dykes of the Ukrainian Shield. Part 1. Mafic dykes swarms. Ibid., № 3 (301), P. 56-61 (in English).

29. Shatalov N.N., Shatalov A.N. Dykes of the Ukrainian Shield. Part 2. Ore presence in the dykes. Там же. 2002c. № 4 (302). C. 50-55.

Shatalov N.N., Shatalov A.N., 2002c. Dykes of the Ukrainian Shield. Part 2. Ore presence in the dykes. Ibid., № 4 (302), P. 50-55 (in English).

30. Shatalov N.N., Shatalov A.N. Dykes of Precambrian rare-metal ongonites of the East-European platform. Там же. 2007. № 2 (319). С. 51-56.

Shatalov N.N., Shatalov A.N., 2007. Dykes of Precambrian rare-metal ongonites of the East-European platform. Ibid., № 2 (319), P. 51-56 (in English).

31. Shatalov N.N., Shatalov A.N. Kamennye mogily dyke belt of Near-Azovian region. Там же. 2011. № 4 (337). C. 62-73.

Shatalov N.N., Shatalov A.N., 2011. Kamennye mogily dyke belt of Near-Azovian region. Ibid., № 4 (337), P. 62-73 (in English).

Статья поступила 12.04 .2013 